\title{
Theorising mobility justice
}

Mimi Sheller*

Introduction

Mobility justice is one of the crucial political and ethical issues of our day, when the entire world faces the urgent question of how to make the transition to more environmentally sustainable and socially just mobilities. All around the world today, the challenges of precarious access to mobility (and unsafe or risky mobilities) produce the sharpest contours of uneven mobility. Urban, regional, and international governing bodies are grappling with a series of crises related to how we move: an urban crisis of pollution and congestion, a global refugee crisis of borders and humanitarianism, and a climate crisis of global warming and decarbonisation. These concerns may look quite different from the Global South than from the Global North, but the regions are interconnected and the production of unjust mobilities is a transnational and planetary problem that demands concerted efforts for social change.

Drawing on my forthcoming book Mobility justice (Verso, 2018), this article seeks to think across these crises showing how each is part of a wider disturbance in prevailing institutions concerned with the management of mobilities and immobilities, circulation and borders, and mobilization as well as demobilization. Mobility justice offers a new way to think across the micro, meso, and macro scales of transitioning toward more just mobilities. I seek to situate debates over sustainable transportation 
and low-carbon transitions in the context of wider unequal mobility regimes, including consideration of the rights to cross-border mobility of refugees and migrants, but also at issue are the larger macro-mobilities of a planetary scale and the smaller micro-mobilities at the bodily scale (especially as inflected by race, gender, disability, and sexuality) and even at the nanoscale (for example, concerning viral mobilities, chemical pollutants, or hunger, obesity and conversion of energy into fat).

Elite mobilities and refugee movements stand in some relation to each other, and are also not separable from climate change and urban resilience, or the mobilities of hunger and disease, military mobilities and global logistics chains, racial segregation and gendered sexual policing of everyday bodily mobility, eviction and homelessness. Current approaches to transport justice, environmental justice, and even spatial justice have not spent enough time showing how embodied differences in class, gender, race, ethnicity, nationality, sexual identity and physical ability influence accessibility and interact with the mobility regimes and control systems that reproduce uneven mobilities. Truly addressing the injustices of unequal mobilities requires that we develop a deeper understanding of how uneven mobility relates not only to how we move around cities, but also gendered and racialized colonial histories and neocolonial presents; along with the geo-ecological and geo-political bases of planetary mobilities in extractive industries such as mining and energy production.

The new mobilities paradigm beyond the Global North

Over the past fifteen years a new interdisciplinary approach to the study of mobilities has been emerging across the social sciences, as well as touching the humanities and more "applied" fields of design, urban planning, and transport studies. For me it began when John Urry and I organized the Alternative Mobility Futures conference at Lancaster University, U.K., in January 2004 and then launched the Centre for Mobilities Research. The conference led to several publications that became influential in announcing "the new mobilities paradigm" (Sheller and Urry, 2006), including my article with Urry which introduced the 2006 special issue of Society \& Space that we co-edited on "materialities and mobilities". The conference also involved a workshop on mobility and mobile media, which led to our edited collection "Mobile technologies of the city". And finally, it influenced our decision to launch the journal Mobilities, founded in 2005 along with co-editor Kevin Hannam, with its first issue published in January 2006 with the editorial introduction on "Mobilities, immobilities and moorings" (Hannam, Sheller and Urry, 2006).

At the same time, a number of cultural geographers in the U.K. had also been gathering projects around concepts of mobility, especially involving the work led by 
Tim Cresswell, Peter Adey, Peter Merriman, and other geographers. Their work led to a whole series of important publications that have made the concept of mobilities central to the discipline of geography (see Cresswell 2006, 2011, 2012, 2014; Adey et al., 2014; Adey, 2017). Meanwhile, historians involved in the International Association for the History of Transport, Traffic and Mobility (т2M) were likewise beginning to broaden the notion of transport history towards a more diverse history of mobilities, which eventually led to the launch of the journal Transfers: Interdisciplinary Journal of Mobility Studies, edited by Gijs Mom. More informal research networks also began to emerge, including the Cosmobilities Network and various other "mobilities networks" including a Mediterranean mobilities network, a Pan-American mobilities network, and eventually an Aotearoa/New Zealand Mobilities network and the recently launched Australian Mobilities Network, all of which maintained electronic mail lists and organized occasional conferences and workshops.

The field of mobilities studies began with discussions of "automobility" as a dominant system, but came to include research on the combined movements of people, objects, and information in all of their complex relational dynamics in many locations and across many scales. It involves new theoretical approaches and methodological innovations for studying both mobilities and immobilities, speed and barriers, as well as the representations and meanings attached to such movement (Sheller and Urry, 2006; Sheller and Urry, 2016). Mobilities research focuses on the constitutive role of movement within the workings of most social institutions and social practices, and focuses on the organization of power around systems of governing mobility and immobility at various scales. Such systems are culturally shaped and politically governed by mobility regimes that govern who and what can move (or stay put), when, where, how and under what conditions. Mobilities research focuses not simply on movement per se, but on "the power of discourses, practices and infrastructures of mobility in creating the effects of both movement and stasis" (Sheller, 2011, p. 2).

Since it would be unwieldy to try review the field as a whole, here I want to focus especially on developments relating to issues of power, inequality, and justice. I would argue that issues of uneven motility and of mobility rights, ethics and justice have become crucial to the field (Cresswell, 2006; Bergmann and Sager, 2008). There has been increasing attention to concepts such as "differential mobility" (Frith, 2012), "uneven mobilities" (Sheller, 2015), "motility” or potential mobility (Flamm and Kaufmann, 2006; Kellerman, 2012), “mobility capabilities” (Kronlid, 2008), and questions of power, justice and mobility rights (Bærenholdt, 2013; Faulconbridge and Hui, 2016). Mobilities research also has a normative dimension: it engages not 
only in critical analysis of historical and existing mobility systems, but also models future transitions that might help to bring about alternative cultures of mobility. It asks how relations of mobility and immobility are culturally made within and through social practices. What is the new mobilities paradigm?

1. A new way of thinking about social worlds as emergent from complex and multiscalar mobile relations, flows, circulations, and their temporary moorings (rather than sedentary epistemologies and methodological nationalism).

2. Mobilities research provides insight into the social practices and material agencies of contemporary mobile lives. It examines the complex interconnections between physical, virtual, communicative, and imaginative mobilities, including the movement of people, objects, information, capital, and resources - as well as their immobilities.

3. We also focus on understanding how meanings, representations, and mobility discourses frame phenomena as moving or still, fast or slow, mobile or immobile.

4. A method and collaborative site of action_for experimenting with new mobilities, exploring mobility ethics, and developing explicitly normative frames for instigating mobility justice.

5. There is a politics of mobility, organized around "constellations" of movement, meaning and practice, as Tim Cresswell describes it (Cresswell, 2010). Mobilities are uneven, differential, and unequal, and come together through these combined lived experiences that are both physical and meaningful.

Mobilities research therefore encompasses not only study of the corporeal travel of people and the physical movement of objects (e.g., transportation systems), but also imaginative travel, virtual travel, and communicative travel (Urry, 2007), which are various kinds of mediated mobilities that involve the circulation of images and representations, while also enabling and coercing (some) people to live more "mobile lives" (Elliott and Urry, 2010). By bringing together studies of migration, transportation, infrastructure, transnationalism, mobile communications, imaginative travel and tourism, these various new approaches to the study of mobilities are especially able to highlight the relation between local and global "power-geometries" (Massey, 1991). We can begin to see that uneven powers of "motility" - meaning the capability for mobility and control over the mobility of others - and differential "accessibility" to various kinds of spaces and social goods are not just the result of racial, gendered, classed, sexed, and other formations, but are also productive of those hierarchical systems of differentiation, through various kinds of enablement and disablement. 
However, over this decade it has also become clearer that we need both a deeper historicizing of mobilities research in terms of colonial histories, global geographies, and the global impacts of neoliberalism, as well as a deeper ecologizing of the material resource bases of mobility in extractive industries (Sheller, 2014). On the one hand, a great deal of mobilities research has focused on contemporary urban issues, especially in the Global North, issues such as sustainable post-automobility mobility transitions involving redesigning cities for bicycling, walking, and public transit; the problematic growth of air travel and aeromobilities that promote mobile lifestyles of "mobility pioneers"; or even concerns over crossing borders, whether by tourists, travelers, or migrants. Some have called for greater attention to (im)mobilities in the Global South, to questions of mobility in rural and "peripheral" areas, and to the problems of coerced mobilities and displacement. On the other hand, the strong issues in anthropocentric processes such as commuting, transport systems, traveling, migration, or various leisure mobilities has kept the focus on micro-scale embodied movement, meso-level patterns of mobility and immobility, and occasionally the macro-level structures of governance of mobility regimes. But the ecological problems of the Anthropocene may demand that we focus greater attention on the non-human circulation of energy, metals, water, pollution, and waste. Rather than focusing on how people move, we also need to think about how systems are mobility are built, energized, and impact on larger planetary ecosystems.

Indeed, a focus on the Global South, on non-urban areas, and on ecological concerns leads us to connect together issues of histories of colonialism and extractive industries with more immediate problems of urban life and forms of uneven circulation in the world today, both locally and globally. It also suggests that we might look more closely at the politics of mobility as an ongoing struggle to control or disrupt the mobility regimes that shape power relations.

I began my career studying the "public sphere", democracy formation, and civic participation in post-slavery societies (in which I include my own home-city of Philadelphia). My PhD dissertation and first book, Democracy after slavery: black publics and peasant radicalism in Haiti and Jamaica (2000), examined how "black publics" in post-emancipation Haiti and Jamaica struggled to build radical democratic societies but were thwarted by liberal and then authoritarian governments. I was fascinated with the question how "subaltern publics" form and how they participate politically. After I joined the Sociology Department at Lancaster University, this led to my first co-authored article with John Urry, "The city and the car" (2000), in which we examined how the automobile was not simply a technology of transport, but had transformed public space, public life, and democratic participation. This led to an interest in what I called "mobile publics" and 
the ways in which mobility transformed both private and public life, as well as the conversations that led to what I have described above as the emergence of the "new mobilities paradigm".

At the same time, however, I was working on my second book, Consuming the Caribbean (Sheller, 2003), which applied a mobilities theoretical lens to look at the Caribbean as a mobile region, built out of the capitalist circulation and consumption of bodies, labor, plants, commodities, representations, texts, and cultures. Thus my own work on mobilities was always informed by a non-Western and postcolonial critical perspective, as well as efforts to understand the exploitative relations between East and West, North and South. This would lead to my later book, Aluminum dreams: the making of light modernity (Sheller, 2014), which traced those connections and (im)mobilities through a material cultural history of the light metal, aluminum, and its basis in bauxite mining around the world, but especially in the Caribbean. I have increasingly tried to merge together my research interests in the Caribbean and Latin America, which has its own conferences, dialogues, and interlocutors, with my research interests in the field of mobilities research, where the participants have tended to be European. The emergence of an interest in "the new mobilities paradigm" in Latin America has provided the perfect opportunity to try to advance these projects on common ground.

Mobility justice and uneven mobilities

The specific trajectory of the field and of my own work, described above, has led me to my latest project: to think more precisely about how we might theorize justice in relation to liberal and neoliberal power, global inequalities, and colonial histories and postcolonial presents of uneven mobilities. In my forthcoming book, Mobility justice, I theorize justice more specifically in relation to concepts of distributive justice, deliberative justice, procedural justice, restorative justice and epistemic justice, which I cannot fully review here. I also contrast concept of transport justice, which I argue is too narrowly focused on transport alone, and spatial justice which is too narrowly focused on the urban scale and is not very mobile. I draw on some ideas from the climate justice literature (e.g., Schlosberg, 2012) and develop a capabilities approach to think about differing capabilities for mobility. This leads to key questions such as these:

- Who is able to exercise rights to mobility and who is not capable of mobility within particular situations? Who is mobile or immobile and why?

- Who governs or controls mobility systems? How have sovereign control and 
disciplinary systems historically produced differently marked bodies as unequal mobile subjects?

- What modes of counter power and subversive mobilities might inform the kinds of moves that can be made to resist, overturn, challenge, or escape these mobility regimes?

- How can we support building greater mobility justice? How can people reclaim the mobile commons?

- What do we mean by "uneven mobility"?

To use the categories that serve to organize the recent Routledge Handbook of Mobilities Research, the unevenness of mobility may take the form of uneven qualities of experience, uneven access to infrastructure, uneven materialities, uneven subjects of mobility, and uneven events or temporalities of stopping, going, passing, pausing, and waiting (Adey et al., 2014). These uneven terrains bring socio-technical infrastructures to the social and political foreground, for they depend not only on the design of the built environment but also on the social practices in which delay, exclusion, turbulence, blockage, and disruption are an everyday experience for those who must dwell in and move through marginalized spaces seeking livelihoods, passage, and asylum (e.g., Fischer, McCann and Auyero, 2014; Mountz, 2010; Graham, 2009). I find these concepts very helpful for thinking about uneven mobility and accessibility as productive of hierarchies of race, ethnicity, class, gender, sexuality and disabilities or impairments via processes of control over differential mobilities.

Uneven mobility, therefore, refers first, to a terrain for movement in which there are divergent pathways, differential access, or partial connectivity; this refers then to built environments, and the ways in which urban space and national space may be splintered in ways that connect some places while disconnecting others. Second it refers to means or modes of movement that have a greater or lesser degree of ease, comfort, flexibility, and safety, with more or less friction, noise, speed, or turbulence; this is suggestive of segregated transportation systems, not just explicit rules as to who can ride different modes, but also class-based exclusions that relegate the poor to more dangerous and uncomfortable means of transport, longer distance commutes, peripheral living spaces and perhaps even homelessness. Third, it refers to spatial patterns, forms of mobility management, and control architectures that govern relations of mobility and immobility, speed and slowness, comfort and discomfort across many scales, including gates, walls, exclusionary regulations, detention centers and prisons. And fourth, it refers to local, regional, urban, national and global systems for control over space, territory, communication, and speed, which produce differential mobility regimes; this means not only border controls, and passport, 
visas, or pass systems, but also control over logistics, energy infrastructure, and the resources that enable more efficient mobility for the elite, and it should be said, for military powers.

Uneven mobilities are crucial to deterritorializing processes and especially forms of elite secession, which underwrite the mobile production of ongoing global inequalities. The right to mobility exists in relation to exclusions from national citizenship and urban access, controlled via policing, fungible borders, gates, passes, and surveillance systems, but also architecture, design and everyday practices that limit the right to the city and to the protection of the state. Even for those within the gates, fragmented public services, hostile policing, and gentrified city centers push the poor to the margins. In the glistening metropolises of densely packed corporate sky scrapers, only the commodified tourism spaces of urban playscapes (Sheller and Urry, 2004) and the exclusive zones of "elite mobilities" and cocooning (Birtchnell and Caletrio, 2014) may occupy the best, cleanest, greenest locations and make use of the newest, fastest infrastructures of transport and communication. Especially in the urban centers of gentrifying global cities in the Global North, the practices of conspicuous consumption and unfettered mobility of elites often stand in obscene contrast to those evicted to the margins and peripheries, unable to access the city, which has increasingly become a staged spectacle of elite privilege and tourist consumption. Such patterns may differ in the Global South, and it remains a crucial area of research to understand the articulation between elite and subaltern mobilities in differing spatial contexts.

\section{The scales of justice}

Next I want to turn to a more specific look at different scales of mobility justice, and begin to propose more positive forms of advancing more just mobilities. The problem of mobility injustice begins with our bodies, and the ways in which some bodies can more easily move through space than others, due to restrictions on mobility relating to gender, race, class, ethnicity, sexuality and physical abilities. Consider the spatial restrictions on the mobility of wheelchair-users, or the limited mobility of racialized minorities under police regimes of white supremacy, or the constrained mobility of women under patriarchal systems of violent domination, or of sexual minorities under heteronormative regimes.

Second, it concerns the shaping of built environments by infrastructures and land use, including the forms of buildings, streets, vehicles, public transit, and other forms of transport infrastructure that have long been part of the making of racially segregated cities, sexually unsafe areas, or places of class exclusion. Consider the social 
movements that have advocated for desegregation of transportation, for transportation justice, for the "right to the city" of the poor, or for women's or LGBTQ rights to public space.

Third, mobility justice pertains to entire urban forms, or what I call, following Neil Brenner and Christian Schmid (2014), "planetary urbanization", including the spatial formation of suburban sprawl, fossil fuel extraction and pipelines, and toxically polluted peripheries. These global structures of uneven mobility are of course shaped by militarization and the control of land, air, and sea as logistical spaces for the movement of troops and weaponry, but also by the power of multinational capital to move around the world and take resources (Brenner, 2014; Cowen, 2014).

Fourth, mobility justice concerns the scale of the nation state, and the control of borders, migration, refugee, and citizenship. It includes visas and passports, interception, securitization, detention, deportation, and wall building, which we have seen in full force recently under the guise of the "refugee crisis" around the world. As more and more people are displaced around the world, both by warfare and scarcities of food and water exacerbated by climate change, these mobility injustices become ever more urgent.

Lastly, mobility justice issues are crucial to understanding the uneven impacts of climate change in relation to spatial injustices and uneven mobilities. Environmental injustices and mobility injustices are two faces of the same problem, each contributing to the other, and they are intertwined with the uneven distribution of access to transport, energy, and the fundamental life requirements of clean air, water, food and shelter. The circulation of waste, pollution, and toxic materials overflows any boundaries, with plastics filling the ocean, electronic waste traveling to dumps around the world, and greenhouse gases changing the composition of the Earth's atmosphere.

\section{Bodily scale}

Beginning with the bodily scale, Elliott and Urry describe network capital as a combination of capacities to be mobile, including appropriate documents, money and qualifications; access to networks at-a-distance; physical capacities for movement; location-free information and contact points; access to communication devices and secure meeting places; access to vehicles and infrastructures; and time and other resources for coordination (Elliott and Urry, 2010, pp. 10-11). There is an uneven distribution of these capacities for potential movement in relation to the surrounding physical, social, and political affordances for movement. We can think of this as different degrees of 'motility', which can be defined as 'the manner in which an 
individual or group appropriates the field of possibilities relative to movement and uses them' (Kaufmann and Montulet, 2008, p. 45); it concerns the potential for mobility. Elites accumulate network capital, while relegating others to situations of slow, encumbered, or vulnerable mobility.

At the scale of the body, we can posit that all people have a right to freedom of bodily movement, without undue constraint imposed from outside. Along with the basic idea of freedom of movement, I propose the following principles of mobility justice that have been (or should be) legally protected at the bodily scale, yet are very much in jeopardy today:

- Habeas corpus: the right to appear before a court of law and have due process if constrained by the state.

- Each individual's mobility shall be constrained by the rule of mutuality: i.e., not trampling, endangering, or depriving others of their capability for mobility.

- Individual mobility shall not be involuntarily restricted by threats of violence, including enforced forms of clothing, segregated means of movement, or unevenly applying temporal or spatial limits.

- Gender and sexual identity shall not be used as the basis for restricting mobility or exclusion from public space.

- Racial, ethnic, or national profiling shall not be used to police entire groups or stop particular individuals from exercising freedom of movement.

\section{Street scale}

Second, mobility justice concerns the shaping of built environments and land use including buildings, streets, vehicles, public transit, and other transport infrastructure that have long been part of the making of racially segregated, automobile dependent cities, as well as creating places of class, gender, sexual, and physical exclusion. Here we can build on the field of transportation justice the following principles:

- Public systems of transport shall not arbitrarily deny access to some groups as against others by physical barriers or denial of service by race, gender, ability etc.

- Public investments in transport systems shall not afford mobility to some groups by imposing undue burdens, externalities, or limitations on others who do not benefit.

- Cities shall ensure equitable provision of public transit and communication infrastructure through a social benefit analysis based on population-level measures of social exclusion and minimum thresholds of accessibility (Martens). 
- Complete Streets policies (which promote greater design attention to all modes of transport and accessibility, including non-motorized modes and public transit) shall be developed to ensure that all modes of moving are afforded space and that streets are not dominated by one mode such as cars.

\section{Extended Urban Scale}

Third, mobility justice pertains to entire "extended" urban forms, their architecture and infrastructure, including the spatial formation of suburban sprawl, fossil fuel extraction and pipelines, mines, power plants and toxically polluted peripheries. "What might it mean", Deborah Cowen asks, "to ground citizenship in the material architectures and social relations of alternative infrastructure, instead of the gate/ ways of corporations and nation states? Could repairing infrastructure be a means of repairing political life more broadly?" (Cowen, 2017).

When we imagine the resilience of cities and mobility systems in the future, we need to consider the problem of automobility as not just one of congestion and pollution, but also as concerned with the spatial "secession" [i.e., to secede, to break away] of elites who are able to provide for their own mobility, security and safety through privatized corridors and special facilities for ease of movement. "Secessionist mobility" may be as simple as moving to the automobilized space of the suburbs (Henderson, 2006), or as elaborate as owning a private island, using offshore banks, and flying in private jets (Sheller, 2009a; Sheller, 2009b). When carbon-hungry kinetic elites resort to the private jet, the helicopter, the high speed train, the yacht, the cocooned limousine, or the semi-militarized sport utility vehicle, they externalize the environmental impacts of high-carbon lifestyles onto others, while also determining spatial development to support gated enclaves, high-rise towers, sanitized pseudo-urban tourist zones, all-inclusive resorts with private beaches, spectacles of consumer capitalism, and eco-resorts that are off limits to locals (Birtchnell and Caletrio, 2014).

\section{National Scale}

Fourth, mobility justice concerns the control of borders, migration, refugee policy, and citizenship. It includes all forms of visas and passports, interception, securitization, detention, deportation, and wall building, which we have seen in full force recently in new forms of "border work" and "mobile borders" (Vukov and Sheller, 2013). Tamara Vukov describes the political implications of this struggle for mobility justice, and offers some ideas towards a vision of mobility justice, including first, 
"the building of a world in which safe, accessible, and just forms of movement and dwelling are open and available to all". Secondly, she calls for "an end to the many macro and micro forms of forced mobility and displacement (from colonial and war-based displacements to deportation and evictions due to gentrification)". And finally, she also calls for "The dismantling of imposed forms of immobility, including detention, incarceration, the legacy of colonial confinement (such as reservations) and separation walls and barriers" (Vukov, 2015). Existing social movements have already made these scale-jumping connections, from the prison justice movement to the migrant rights, refugee protection, and anti-border-wall protests.

At this scale of the nation and transnational movements, we can add these dimensions of mobility justice:

- All people shall enjoy a right to exit and re-enter the territory from which they originate.

- There is a right to refuge for those fleeing violence, persecution, and loss of domicile by war.

- People displaced by climate change shall have a right to resettlement in other countries, especially in those countries that contributed most to climate change.

- There is a right to freedom of movement across borders for any temporary purposes defined by law (tourism, education, temporary work etc.)

- No one should be detained or deported without due process.

- Immigration law shall not be used to exclude entire categories of persons on the basis of race, religion, ethnicity, nationality, sexuality, or health status.

\section{Planetary Scale}

Lastly, I suggest that global environmental injustices and mobility injustices are two faces of the same problem, each contributing to the other, and they are intertwined with the uneven distribution of access and harms of logistical space, energy infrastructure, and the fundamental life requirements of clean air, water, food, and shelter. Access to energy, and the minerals and metals that make up transportation systems, are a crucial dimension of such elite mobilities. The potential for mobility is grounded in where energy for transportation is sourced, where it is exported, and who uses most of it. Kinetic elites are monopolizing control over energy, water, and mineral rights, using their power to control global resources that are becoming increasingly scarce. As populations find themselves vulnerable to a changing climate and threatened with loss of access to water, energy, or food, issues of security will increasingly come to the fore - including the potential for political unrest and 
state securitization brought on by climate change and associated urban disasters, as Stephen Graham has explored in his work on Disrupted cities (Graham, 2009). As mobility becomes rationed or far more highly priced due to the politics surrounding the unsustainability of current mobility systems, the inequalities of network capital will be thrown into sharper relief. Ultimately these elite mobilities are drivers of uneven global topographies, which are linked to deeper geo-ecologies of energy use and resource extraction. At this planetary scale:

- Principles of climate justice and environmental justice suggest that mobility consumed in one place should not externalize waste or pollution on other regions without legitimately agreed upon reparations but also protection of non-human entities.

- Those industries and countries that have contributed the most to greenhouse gases and other forms of pollution shall have a responsibility of reparative justice to limit the impacts of their actions on others and to restore the atmosphere and environments as far as possible.

- Those displaced by climate change shall have a right to resettlement in other countries, and especially in those countries that contributed most to climate change.

- Protection of the planetary commons (oceans, seafloor, air, Antarctica, and extraplanetary bodies) shall outweigh any rights to global free trade or private rights to resource extraction.

- All states shall be party to world forums at which carbon budgets are agreed upon and reductions in greenhouse gases regularly measured and met.

- A global trust fund shall be established into which polluters pay in order to meet the costs of urgent global climate change mitigation.

Each of these aspects of mobility injustice calls for greater attention to the longer histories of colonial, racial, imperial, and military mobility that inform contemporary global economies; and to the deeper geo-ecologies of resource extraction and energy use that support their infrastructures. We need to do a better job of tracing the historical patterns informing today's uneven mobilities, including their military, colonial, and racial histories.

\section{Conclusion: a manifesto for mobility justice}

If we seek to abide by the principles of mobility justice, what kind of built forms, social practices, infrastructures, and narratives will support a more just mobility? Where should we direct our attention in building more just mobility cultures and 
forms of governance across multiple scales at once? I have argued that in thinking about bodily space, street space, urban space, national space, and even planetary space as racialized, gendered, and uneven, we can extend the insights of mobilities research not only into understanding micro-level interactions, and meso-level urban politics, but also macro-level global relations of unequal mobility. A combined transition toward sustainable mobility and mobility justice therefore requires more than changing how much energy we use in everyday life; it more fundamentally requires greater equity in the distribution of network capital and capabilities for motility, locally and globally.

It is incumbent upon us to expose more thoroughly the relation between such unequal mobility systems and uneven spatialities not only as forms of biopolitical governance of mobility but also as sites of potential resistance. The multi-scalar approach to mobility justice that I have summarized here includes a multi-layered politics of mobility that we could sum up as a kind of Manifesto to take action in a wide range of domains:

- Struggles over everyday embodied relations of racialization, gender, age, disability, sexuality, etc. which inform uneven freedoms of mobility and unequal capabilities for motility;

- Struggles for the right to the city and the public sphere, often with a politics of occupation and presence in public space that disrupts normalized mobility spaces and offers epistemic alternatives;

- Struggles over ethical spaces for contesting borders, migration, and other kinds of transnational mobility - slavery, trafficking, deportation, refugees etc. - in contested contexts of securitization and militarization;

- Struggles over the just circulation of goods, resources, energy, etc. in a global capitalist system that lacks procedural justice in the distribution of planetary matter and in the logistics infrastructures that move that stuff.

In conclusion, a more robust and comprehensive theory of mobility justice can help us address the combined "crises" of climate change, sustainable urban transitions, resource depletion and global migrations. These "crises" are part of a common phenomenon, which shares its origins with other uneven mobilities that impact everyday life. However, one aim is to shift away from the language of crisis towards a more productive way of framing these dilemmas and proposing how to deal with them. Mobility justice is an overarching concept for thinking about how power and inequality inform the governance and control of movement, shaping the patterns of unequal mobility and immobility in the circulation of people, resources, and 
information. We can think about mobility justice occurring at different scales, from micro-level embodied interpersonal relations, to meso-level issues of urban transportation justice and the "right to the city", to macro-level transnational relations of travel and borders, and ultimately global resources flows and energy circulation. Ultimately I argue that we urgently need to connect these scales of the body, street, city, nation, and planet into one overarching theory of mobility justice.

\section{Bibliographic References}

Adey, P. (2017), Mobility. New revised edition. London, Routledge.

AdEY, P.et al. (2014), The routledge handbook of mobilities. London, Routledge.

Bærenholdt, J. O. (2013), “Governmobility: The powers of mobility”. Mobilities, 8 (1): 20-34.

Bergmann, S. \& SAGer, T. (eds.). (2008), The ethics of mobilities: rethinking place, exclusion, freedom and environment. Aldershot, Ashgate.

Birtchnell, T. \& Caletrio, J. (eds.). (2014), Elite mobilities. London, Routledge.

BRENNER, N. (ed.). (2014), Implosions/explosions: towards a study of planetary urbanization. Berlin, Jovis.

Brenner, N. \& SChmid, C. (2014), “Planetary urbanization”. In: Brenner, N. Implosions/ explosions: towards a study of planetary urbanization. Berlin, Jovis.

Cowen, D. (2014), The deadly life of logistics: mapping violence in global trade. Minneapolis, University of Minnesota Press.

Cowen, D. (2017), “Disrupt the flows: war against DAPL and planetary annihilation”. Available in: https://itsgoingdown.org/disrupt-flows-war-dapl-planetary-annihilation/, consulted on: $6 / 12 / 2016$.

Cresswell, T. (2006), On the move: mobility in the modern western world. London, Routledge.

Cresswell, T. (January 2010), “Towards a politics of mobility”. Environment and Planning D: Society and Space. 28 (1): 17-31.

Cresswell, T. (2011), "Mobilities I: catching up”. Progress in Human Geography. 35 (4): 550-8.

Cresswell, T. (2012), “Mobilities II: still”. Progress in Human Geography. 36 (5): 645-653.

Cresswell, T. (2014), "Mobilities III: moving on”. Progress in Human Geography. 38 (5): $712-21$

Elliott, A. \& Urry, J. (2010), Mobile lives. London, Routledge.

Faulconbridge, J. \& Hui, A. (2016), “Traces of a mobile field: ten years of mobilities Research". Mobilities, 11 (1): 1-14.

FISCHER, B. et al. (eds.). (2014), Cities from scratch: poverty and informality in urban Latin America. Durham, Duke University Press.

Flamm, M. \& Kaufmann, V. (2006), “Operationalising the concept of motility: a qualitative study". Mobilities. 1 (2): 167-89. 
FRITH, J. (2012), "Splintered space: the smartphone as the screen to the city”. Mobilities, 7 (1): 131-149.

Graham, S. (ed.). (2009), Disrupted cities: when infrastructure fails. New York and London, Routledge.

Hannam, K. et al. (2006), "Mobilities, immobilities, and moorings". Mobilities, 1 (1): 1-22.

Henderson, J. (2006), “Secessionist automobility: racism, anti-urbanism, and the politics of automobility in Atlanta, Georgia”. International Journal of Urban and Regional Research, 30 (2): 293-307.

Kaufmann, V. \& Montulet, B. (2008), "Between social and spatial mobilities: the issue of social fluidity”. In: Canzler, W.; Kaufmann, V. \& Kesselring, S. (eds.). Tracing mobilities: towards a cosmopolitan perspective. Farnham, Ashgate, pp. 37-56.

Kellerman, A. (2012), "Potential mobilities”. Mobilities, 7 (1): 171-83.

Kronlid, D. (2008), “Mobility as capability”. In: Uteng, T. P. \& Cresswell, T. (eds). Gendered mobilities. Aldershot, Ashgate, pp. 15-34.

Massey, D. (1991), "A global sense of place”. Marxism Today, 35 (6): 24-29.

Mountz, A. (2010), Seeking asylum: human smuggling and bureaucracy at the border. Minneapolis, University of Minnesota Press.

Schlosberg, D. (2012), "Climate Justice and capabilities: a framework for adaptation policy”. Ethics and International Affairs, 26 (4): 445-461.

SHeller, M. (2000), Democracy after slavery: black publics and peasant radicalism in Haiti and Jamaica. London and Basingstoke, Macmillan Caribbean.

Sheller, M. (2003), Consuming the Caribbean: from Arawaks to Zombies. London and New York, Routledge.

SHELleR, M. (2009a), "Infrastructures of the Imagined island: software, mobilities and the architecture of Caribbean Paradise”. Environment and Planning A, 41: 1386-1403.

Sheller, M. (2009b), “The New Caribbean complexity: mobility systems, tourism and the re-scaling of development”. The Singapore Journal of Tropical Geography, 30: 189-203.

Sheller, M. (2011), “Mobility”. Sociopedia. International Sociological Association.

SHELler, M. (2014), Aluminum dreams: the making of light modernity. Cambridge, MA, MIT Press.

Sheller, M. \& URry, J. (2000), “The city and the car". International Journal of Urban and Regional Research, 24: 737-57.

Sheller, M. \& URry, J. (2003), "Mobile transformations of 'public' and 'private' life”. Theory, Culture and Society, 20 (3): 107-125.

Sheller, M. \& Urry, J. (2006), “The New Mobilities Paradigm”. Environment and Planning A, 38 (2): 207-26.

Sheller, M. \& UrRy, J. (2016), "Mobilising the new mobilities paradigm”. Applied Mobilities, 1 (1). 
Sheller, M. \& URry, J. (eds.). (2004), Tourism mobilities: places to play, places in play. London, Routledge.

Sheller, M. \& URry, J. (eds.). (2006), Mobile technologies of the city. London, Routledge.

Urry, J. (2007), Mobilities. Cambridge, Polity Press.

Vukov, T. (2015), "Strange moves: speculations and propositions on mobility justice". In: Montegary \& White (eds.). Mobile desires: the politics and erotics of mobility justice. Palgrave Macmillan.

Vukov, T. \& Sheller, M. (2013), "Border work: surveillant assemblages, virtual fences, and tactical counter-media”. Social Semiotics, 23 (2): 225-41.

\section{Abstract}

Theorising mobility justice

Mobility justice is one of the crucial political and ethical issues of our day, when the entire world faces the urgent question of how to make the transition to more environmentally sustainable and socially just mobilities. All around the planet urban, regional, and international governing bodies are grappling with a series of crises related to how we move: an urban crisis of pollution and congestion, a global refugee crisis of borders and humanitarianism, and a climate crisis of global warming and decarbonisation. This article seeks to think across these crises showing how each is part of a wider disturbance in prevailing institutions concerned with the management of mobilities and immobilities. Mobility justice offers a new way to think across the micro and macro scale of transitioning toward more just mobilities.

Keywords: Mobility; Justice; Urban crisis; Borders; Climate change.

\section{Resumo}

Teorizando sobre "mobilidades justas"

"Mobilidades justas" configuram uma das questões políticas e éticas cruciais de nossos dias, quando o mundo enfrenta a questão urgente de como fazer a transição para mobilidades ambientalmente mais sustentáveis e socialmente mais justas. Em todo o planeta, órgãos governamentais urbanos, regionais e internacionais estão lidando com uma série de crises relacionadas aos deslocamentos: uma crise urbana em torno da poluição e do congestionamento, uma crise global de fronteiras e de humanitarismo face aos refugiados, e uma crise climática imposta pelo aquecimento global e pela necessidade de descarbonização. Este artigo busca pensar sobre tais crises, mostrando como cada uma faz parte de distúrbios mais amplos nas instituições responsáveis pela gestão de mobilidades e imobilidades. Na interface entre mobilidade, equidade e justiça, ergue-se uma nova maneira de pensar, desde a escala micro à macro, sobre a transição para mobilidades mais justas. Palavras-chave: Mobilidade; Justiça; Crise urbana; Fronteiras; Mudança climática. 
Texto recebido em 29/1/2018 e aprovado em 1/2/2018.

DOI: $10.11606 / 0103-2070 . t s .2018 .142763$

MIMI SHELlER é professora de sociologia na Drexel University (EUA), diretora do Center for Mobilities Research and Policy (Reino Unido), e presidente do T2M.org. E-mail: mimi.sheller@ drexel.edu.

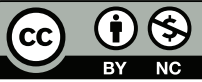

